\title{
AGRONOMIC PERFORMANCE OF CASTOR UNDER DIFFERENT
} GROWING CONDITIONS

\author{
DESEMPENHO AGRONÔMICO DE MAMONA SOB DIFERENTES CONDIÇÕES DE \\ CULTIVO
}

\section{Francisco Eduardo TORRES'; Paulo Eduardo TEODORO²; Fernanda Baptistella HERNANDES ${ }^{3}$; Reliane Lima FERNANDES ${ }^{3}$; Anna Catharina GOMES ${ }^{4}$; Kamila Vieira LOPES ${ }^{2}$}

1. Engenheiro Agrônomo, Doutor em Fitotecnia, Universidade Estadual de Mato Grosso do Sul - UEMS/UUA, Aquidauana, MS, Brasil; 2. Discentes do Programa de Pós-Graduação stricto sensu em Agronomia - UEMS/UUA, Aquidauana, MS, Brasil. eduteodoro@hotmail.com; 3. Discente do Curso de Agronomia da UEMS/UUA, Aquidauana, MS, Brasil; 4. Engenheira Agrônoma pela UEMS/UUA, Aquidauana, MS, Brasil.

\begin{abstract}
Castor has emerged as an oilseed species capable of meeting the demand of the Brazilian market. Thus, there is a need for studies to evaluate the different growing conditions that this species can be cultivated in order to subsidize their production. The study aimed to evaluate the influence of different growing conditions on agronomic performance of seven castor bean cultivars grown in Savanna-Pantanal ecotone region. The trial was conducted at Universidade Estadual de Mato Grosso do Sul, Aquidauana Campus. Treatments consisted of seven castor bean cultivars (BRS Energia, IAC-2028, IAC-Guarani, BRS Nordestina, BRS Paraguaçu, IAC-80 and IAC-226) and three growing conditions (with weed control and without topdress nitrogen; with topdress nitrogen at $80 \mathrm{~kg} \mathrm{ha}^{-1}$ and with weed control; without weed control and absence of topdress nitrogen) in two agricultural years (2011 and 2012), arranged in randomized block design with three replications in factorial arrangement $(7 \times 3 \times 2)$. The following variables were evaluated: plant height, stem diameter, number of bunches, number of fruits and fruit yield. The cultivars BRS Energia, IAC 2028, IAC Guarani and BRS Paraguaçu obtained greater fruit yield. Topdress nitrogen and weed control provided to cultivars the highest stem diameter, number of bunches, number of fruits and fruit yield.
\end{abstract}

KEYWORDS: Nitrogen fertilizer. Agronomic traits. Ricinus communis L.

\section{INTRODUCTION}

Castor (Ricinus communis L.) is an oilseed belongs to the Euphorbiaceae family, currently being grown in several countries. The crop is have been highlighted mainly for its oil production, which has numerous applications in industrial area, with perspective of use as an energy source in biodiesel production (BELTRÃO et al., 2006; TORRES et al., 2013, 2015a,b).

Brazil is the third largest producer of castor bean (FAO, 2011), with a production of 15,800 tons (CONAB, 2014). However, the national productivity of $180 \mathrm{~kg} \mathrm{ha}^{-1}$ (harvest 2013/2014), is considered low when compared to crop production potential, which according to Severino et al. (2006) and Soratto et al. (2011) exceeds $4,000 \mathrm{~kg} \mathrm{ha}^{-1}$.

It should be emphasized that, to achieve economically viable productivities with the crop, it is necessary to adequately meet the nutritional requirements of the plant (CHIARADIA et al., 2009). Castor is a plant that needs to be grown in very fertile soils to reach good productivity, being the nitrogen $(\mathrm{N})$ the most exported nutrient by the crop. The absence of nitrogen impedes the initial plant growth, because this element is part of protein and amino acids, and their lack delays the initial plant growth for making impossible the carbon incorporation (EPSTEIN; BLOOM, 2006).

Azevedo et al. (2006) claim that another aspect that can affect the castor bean productivity is the presence of weeds since the crop is considered highly sensitive to competition. Weeds compete with the crop for natural resources like soil moisture, light, nutrients, $\mathrm{CO}_{2}$ and polarizing agents (WEISS, 1983). The technologies used in the cultivation of castor bean and weed management are changeable among the different Brazilian regions. This scenario contributes to the occurrence of yield loss due to lack of information on weed control (MACIEL et al., 2008; FERREIRA et al., 2009).

Torres et al. (2015a,b) observed phenotypic adaptability of castor bean cultivars to the CerradoPantanal ecotone, demonstrating the feasibility of the cultivation of this crop in this region. In practical terms, know the growing conditions of this crop implies in the accurately recommendation of practices relating to the management of fertilization and weed control to the farmer, as the use of fertilizers, performing weeding, mowing or application of post-emergent herbicides (TORRES et al., 2013). Thus, the survey of this information 
contributes to the understanding of cropping systems that allow the castor bean production expansion in Brazil and the increase of productivity and economic returns for this crop (COSTA et al., 2014).

Given the above, the aim of this study was to evaluate the influence of different growing conditions on the agronomic performance of castor cultivars grown in the Savanna-Pantanal ecotone region.

\section{MATERIAL AND METHODS}

The trial was conducted at the Crop Science sector of the Universidade Estadual de Mato Grosso do Sul, Campus Aquidauna $\left(20^{\circ} 27^{\prime} \mathrm{S}, 55^{\circ} 40^{\prime} \mathrm{W}\right.$ and average altitude of $170 \mathrm{~m}$ ). The soil of the area was classified as Ultisol Dystrophic of sandy texture, with the following features in the layer $0-0,20 \mathrm{~m}$ : $\mathrm{pH}\left(\mathrm{H}_{2} \mathrm{O}\right)=6.2 ; \mathrm{Al}$ exchangeable $\left(\mathrm{cmol}_{\mathrm{c}} \mathrm{dm}^{-3}\right)=$ 0.0; $\mathrm{Ca}+\mathrm{Mg}\left(\mathrm{cmol}_{\mathrm{c}} \mathrm{dm}^{-3}\right)=4.3 ; \mathrm{P}\left(\mathrm{mg} \mathrm{dm}^{-3}\right)=41.3$; $\mathrm{K}\left(\mathrm{cmol}_{\mathrm{c}} \mathrm{dm}^{-3}\right)=0.2$; Organic matter $\left(\mathrm{g} \mathrm{dm}^{-3}\right)=$ 19.7; $\mathrm{V}(\%)=45.0 ; \mathrm{m}(\%)=0.0 ;$ Sum of bases $\left(\mathrm{cmol}_{\mathrm{c}} \mathrm{dm}^{-3}\right)=4.5 ; \operatorname{CEC}\left(\mathrm{cmol}_{\mathrm{c}} \mathrm{dm}^{-3}\right)=5.1$.

The experimental design used was randomized blocks with three replications in factorial arrangement $(7 \times 3 \times 2)$. The experimental units consisted of four rows of plants with $15.0 \mathrm{~m}$ in length for each treatment, being divided into three sub-plots of $5.0 \mathrm{~m}$ each, spaced $1.0 \times 1.0 \mathrm{~m}$ between rows and between plants respectively. The treatments consisted of seven castor bean cultivars (BRS Energia, IAC-2028, IAC-Guarani, BRS Nordestina, BRS Paraguaçu, IAC-80 and IAC-226), evaluated in two crop years (2010/2011 and 2011/2012) and three growing conditions (C), described below:

- C1: without weed control throughout the crop cycle and without topdress nitrogen $(\mathrm{N})$;
- $\quad$ C2: with weed control during the crop cycle and with topdress nitrogen at $80 \mathrm{~kg} \mathrm{ha}^{-1}$, distributed individually on each plant at 55 days after sowing.

- $\quad$ C3: with weed control and absence of topdress nitrogen.

The trial was conducted for two consecutive crop years (2010/2011 and 2011/2012), using the same treatments, following the crop treatments and the evaluation methodology follow mentioned. Sowing was carried out on 10 December, 2010 and 2011. The preparation of area consisted of a mechanical and a weeding harrow, with the holes with a depth of $15 \mathrm{~cm}$, manually opened with the aid of a hoe. The commercial chemical fertilizer formulation 04-20-20 (NPK) was distributed manually at the bottom of the pits, corresponding to $30 \mathrm{~g} \mathrm{hole}^{-1}$. After fertilization was added an amount of soil on compost and planted a seed per hole, which were covered again with soil.

The evaluations were initiated at 90 days after sowing, when the cultivars were in the growth stage R12, i.e. where $90 \%$ of fruits have reached their physiological maturity, characterized by the appearance of dry fruits (MOSHKIN, 1986). It were evaluated in five plants per plot the following variables: plant height $(\mathrm{PH})$, stem diameter $(\mathrm{SD})$, number of bunches (NB), number of fruits (NF) and fruit yield (YIE), as carried out by Torres et al. (2013). In Table 1, are contained all data of maximum and minimum temperature, maximum and minimum air relative humidity and rainfall during the trial developmental period in the agricultural years 2010/2011 and 2011/2012, collected from the weather station installed in the experimental area. Climate results over the experiments are similar to those reported in other studies with castor (TORRES et al., 2013, 2015) and indicate that climatic factors were not limiting for culture.

Table 1. Meteorological data during the period of trial conduction. Aquidauana, MS, 2012.

\begin{tabular}{ccccccccccc}
\hline & \multicolumn{3}{c}{ Temperatures $\left({ }^{\circ} \mathrm{C}\right)$} & \multicolumn{6}{c}{ Relative humidity $(\%)$} & \multicolumn{2}{c}{ Rainfall $(\mathrm{mm})$} \\
\cline { 2 - 10 } & \multicolumn{2}{c}{$2010 / 2011$} & \multicolumn{2}{c}{$2011 / 2012$} & \multicolumn{2}{c}{ 2010/2011 } & $2011 / 2012$ & $2010 / 2011$ & $2011 / 2012$ \\
\cline { 2 - 10 } & Max. & Min. & Max. & Min. & Max. & Min. & Max. & Min. & & ------ \\
\hline Dec. & 40.0 & 26.9 & 38.8 & 15.1 & 100.0 & 13.0 & 96.0 & 17.0 & 210.2 & 80.4 \\
Jan. & 35.8 & 20.8 & 39.1 & 18.5 & 97.0 & 35.0 & 97.0 & 23.0 & 351.4 & 122.6 \\
Feb. & 34.8 & 22.0 & 37.0 & 20.7 & 96.0 & 46.0 & 96.0 & 30.0 & 247.4 & 115.2 \\
Mar. & 33.8 & 20.4 & 35.9 & 13.3 & 97.0 & 45.0 & 97.0 & 25.0 & 260.8 & 145.8 \\
Apr. & 34.5 & 16.1 & 35.0 & 12.9 & 97.0 & 31.0 & 96.0 & 37.0 & 56.2 & 104.8 \\
May. & 33.3 & 11.0 & 32.9 & 9.0 & 98.0 & 28.0 & 98.0 & 26.0 & 4.6 & 35.0 \\
Jun. & 34.4 & 10.9 & 32.5 & 10.2 & 98.0 & 25.0 & 98.0 & 30.0 & 8.2 & 187.4 \\
Jul. & 35.6 & 9.5 & 34.3 & 14.2 & 97.0 & 19.0 & 99.0 & 22.0 & 23.6 & 10.2 \\
\hline
\end{tabular}


Data were submitted to individual variance analysis. For all variables this trial, the relation among the residual mean square of the individual variance analysis did not exceed the relation 7:1, allowing following the implementation of joint analysis of the trials (BANZATTO; KRONKA, 2006). Data were subjected to analysis of variance and when the effects were significant, was performed mean comparison by Tukey's test at $5 \%$ probability. All analyzes were performed using the statistical application Sisvar (FERREIRA, 2011).

\section{RESULTS AND DISCUSSION}

The joint analysis has not detected significant effect of crop years and no interaction with any other evaluated factor. There was no significant interaction between cultivars and growing conditions. However, the joint analysis revealed significant differences among the cultivars ( $\mathrm{p}<0.01$ ) for all variables (Table 2). The cultivar BRS Paraguaçu obtained the highest mean values for $\mathrm{PH}$ and $\mathrm{SD}$, but not statistically differed from the cultivars BRS Nordestina, IAC Guarani and IAC 226.

Table 2. Mean values of the variables plant height (PH), stem diameter (SD), number of bunches (NB), number of fruits (NF) and yield fruit (YIE) of seven castor bean cultivars, in two crop years.

\begin{tabular}{llllll}
\hline Cultivars & PH $(\mathrm{cm})$ & SD $(\mathrm{mm})$ & NB & NF & YIE $\left(\mathrm{kg} \mathrm{ha}^{-1}\right)$ \\
\hline BRS Energia & $157.00 \mathrm{~b}$ & $22.79 \mathrm{c}$ & $2.62 \mathrm{a}$ & $110.30 \mathrm{~b}$ & $3,001.23 \mathrm{a}$ \\
IAC 2028 & $180.22 \mathrm{~b}$ & $32.73 \mathrm{~b}$ & $1.39 \mathrm{c}$ & $125.56 \mathrm{ab}$ & $1,841.19 \mathrm{abc}$ \\
IAC Guarani & $200.87 \mathrm{ab}$ & $35.24 \mathrm{ab}$ & $1.41 \mathrm{c}$ & $162.62 \mathrm{ab}$ & $2,330.46 \mathrm{ab}$ \\
BRS Nordestina & $210.21 \mathrm{ab}$ & $40.39 \mathrm{ab}$ & $1.74 \mathrm{bc}$ & $140.79 \mathrm{ab}$ & $1,283.38 \mathrm{bc}$ \\
BRS Paraguaçu & $238.16 \mathrm{a}$ & $42.58 \mathrm{a}$ & $2.09 \mathrm{ab}$ & $169.96 \mathrm{ab}$ & $1,764.37 \mathrm{abc}$ \\
IAC 226 & $193.33 \mathrm{ab}$ & $33.33 \mathrm{ab}$ & $1.48 \mathrm{c}$ & $194.89 \mathrm{a}$ & $1,166.13 \mathrm{bc}$ \\
IAC 80 & $154.03 \mathrm{~b}$ & $31.01 \mathrm{bc}$ & $1.17 \mathrm{c}$ & $116.87 \mathrm{~b}$ & $559.02 \mathrm{c}$ \\
\hline F & $4.72^{*}$ & $9.62^{*}$ & $14.91^{*}$ & $3.96^{*}$ & $7.45^{*}$ \\
CV $(\%)$ & 20.79 & 26.09 & 22.34 & 25.50 & 23.44 \\
\hline
\end{tabular}

*: Significant at $1 \%$ probability by F-test; Means followed by different letters in the same column differ by Tukey's test at $5 \%$ probability.

The average $\mathrm{PH}$ was $190.5 \mathrm{~cm}$, value greater than those obtained by Ferreira et al. (2009), Silva et al. (2007) and Souza-Schlick et al. (2011), which were 37, 58 and 136, respectively. The same occurred for SD whose average value of $34 \mathrm{~mm}$ was similar to the results obtained by these authors. Cavalcanti et al. (2004), to evaluate the growth of castor bean cultivars, observed at 60 days after sowing an average of $21.1 \mathrm{~mm}$ for the stem diameter of the variety BRS 149 Nordestina, also lower than the value obtained in this study.

BRS Energia and BRS Paraguaçu showed greater NB (2.62 and 2.09, respectively). For the variable NF, IAC 226 had the highest average, statistically differing only from BRS Energia and IAC 80. The cultivar BRS Energia showed greater YIE, however, without statistically differ from the IAC 2028, IAC Guarani and BRS Paraguaçu. Similar results were obtained for Torres et al. (2015a), which verified higher yield grain for these cultivars.

By the joint analysis there was difference ( $>$ $>0.05$ ) among the growing conditions for SD, $\mathrm{NB}, \mathrm{NF}$ and YIE, where the $\mathrm{C} 3$ condition provided the highest average values (Table 3 ). Castor bean is a C3 photosynthetic metabolism plant, characterized by low photosynthetic efficiency, slow initial growth and a low capacity to compete for resources with other species (AZEVEDO et al., 2007; BELTRÃO et al., 2006). According to Azevedo et al. (2006) and Torres et al. (2013), the competition with weeds can cause up to $86 \%$ reduction in castor productivity. In this context, the weed control contributed to obtain greater values for the variables $\mathrm{SD}, \mathrm{NB}, \mathrm{NF}$ and YIE.

Azevedo et al. (2006), evaluating the critical period of weed competition with castor bean verified that the absence of weeds resulted in a greater stem diameter, which was more than $40 \%$ of the value obtained for the variable when in the presence of weeds.

Another aspect to be considered in the improvement of agronomic traits of castor bean is nitrogen fertilization, which according to Chaves et al. (2011) is one of the main technologies used in order to increase productivity and profitability of the crop. The castor bean requirement for $\mathrm{N}$ is in a range between 60 to $80 \mathrm{~kg} \mathrm{ha}^{-1}$ for a fruit production around 2,000 kg ha-1 (SILVA et al., 2007), productivity level similar to the obtained in this study. Silva et al. (2007) verified that the addition of mineral nitrogen significantly increased fruit 
production of the crop. Similarly, Chiaradia et al. (2009) found a reduction of $69 \%$ in production when it was not applied $\mathrm{N}$, which reinforces the importance of the contribution of this nutrient for castor bean.

Table 3. Mean values of the variables stem diameter (SD), number of bunches (NB), number of fruits (NF) and yield fruit (YIE) as function of different growing conditions evaluated, in two crop years.

\begin{tabular}{lllll}
\hline Crowing conditions $^{1}$ & SD $(\mathrm{mm})$ & NB & NF & YIE $\left(\mathrm{kg} \mathrm{ha}^{-1}\right)$ \\
\hline C1 & $31,90 \mathrm{~b}$ & $1,67 \mathrm{~b}$ & $129,36 \mathrm{~b}$ & $1.551,24 \mathrm{~b}$ \\
$\mathrm{C} 2$ & $35,09 \mathrm{a}$ & $1,82 \mathrm{a}$ & $169,16 \mathrm{a}$ & $1.970,54 \mathrm{a}$ \\
$\mathrm{C} 3$ & $35,10 \mathrm{a}$ & $1,62 \mathrm{~b}$ & $139,06 \mathrm{ab}$ & $1.597,85 \mathrm{~b}$ \\
\hline F & $4,47^{*}$ & $4,38^{*}$ & $4,08^{*}$ & $4,45^{*}$ \\
CV $(\%)$ & 12,72 & 18,68 & 25,63 & 19,56 \\
\hline
\end{tabular}

: Described in Material and Methods; *: Significant at 1\% probability by F-test; Means followed by different letters in the same column differ by Tukey's test at $5 \%$ probability.

Based on this information, the increase observed for SD, NB, NF and YIE under C2 condition can also be attributed to nitrogen biochemical properties in plants. This nutrient is responsible for several physiological functions such as protein synthesis, and its absorption and distribution is essential for leaf senescence, seed germination, growth and regeneration of reproductive seedlings (RENTSCH et al., 2007).

\section{CONCLUSIONS}

The cultivars BRS Energia, IAC 2028, IAC Guarani and BRS Paraguaçu showed better agronomic performance in the Savanna-Pantanal ecotone region.

Topdress nitrogen together with weed control it is recommended for the management of castor by provided to cultivars greater stem diameter, number of bunches, number of fruits and fruit yield.

RESUMO: A mamona vem se destacando como uma espécie oleaginosa capaz de suprir a demanda do mercado brasileiro. Desta forma, existe a necessidade de pesquisas que avaliem as diferentes condições de cultivo que esta espécie possa ser cultivada, a fim de subsidiar sua produção. O objetivo do trabalho foi avaliar a influência de diferentes condições no desempenho agronômico de cultivares de mamona cultivada na região do ecótono Cerrado-Pantanal. O experimento foi conduzido na Universidade Estadual de Mato Grosso do Sul, Campus de Aquidauana. Os tratamentos consistiram de sete cultivares de mamona (BRS Energia, IAC-2028, IAC-Guarani, BRS Nordestina, BRS Paraguaçu, IAC-80 e IAC-226) e três condições de cultivo (com controle de plantas daninhas e sem adubação de cobertura com N; com adubação de $80 \mathrm{~kg}$ $\mathrm{ha}^{-1}$ de $\mathrm{N}$ e controle de plantas daninhas; sem controle das plantas daninhas e ausência de adubação de cobertura com N) em dois anos agrícolas (2011 and 2012), dispostos em delineamento de blocos ao acaso com três repetições, em esquema fatorial ( 7 x 3 x 2). Foram avaliadas as seguintes variáveis: altura de plantas, diâmetro do caule, número de cachos, número de frutos e produtividade de frutos. As cultivares BRS Energia, IAC 2028, IAC Guarani e BRS Paraguaçu obtiveram maior produtividade de frutos. A adubação nitrogenada em cobertura e o controle de plantas daninhas proporcionaram às cultivares maior diâmetro do colmo, número de cachos, número de frutos e produtividade de frutos.

PALAVRAS-CHAVE: Adubação nitrogenada. Caracteres agronômicos. Ricinus communis L.

\section{REFERENCES}

AZEVEDO, D. M. P.; BELTRÃO, N. E. M.; SEVERINO, L. S.; CARDOSO, G. D. Controle de plantas daninhas. In: AZEVEDO, D. M. P.; BELTRÃO, N. E.M. (Ed.). O agronegócio da mamona no Brasil. 2. ed. Campina Grande: Embrapa Algodão, 2007. p.333-359.

AZEVEDO, D. M. P.; SANTOS, J. W.; SANTOS, T. S.; LEÃO, A. B. Período crítico de competição entre mamoneira e plantas daninhas. Revista Brasileira de Oleaginosas e Fibrosas, Campina Grande, v. 10, n. 1/2, p. 1017-1024, 2006.

BANZATTO, D. A.; KRONKA, S. N. Experimentação agrícola. 4. ed. Jaboticabal: FUNEP, 2006. 237p. 
BELTRÃO, N. E. M.; CARTAXO. W. V.; PEREIRA, S. R.; SOARES, J. J.; SILVA, O. R. R. O cultivo sustentável da mamona no semi-árido brasileiro. Campina Grande: Embrapa Algodão, 2006.

CAVALCANTI, M. L. F.; BARROS JÚNIOR, G.; CARNEIRO, P. T.; FERNANDES, P. D.; GHEYI, H. R.; CAVALCANTI, R. S. Crescimento inicial da mamoneira submetida à salinidade da água de irrigação. Revista de Biologia e Ciências da Terra, Campina Grande, v. 4, n. 1, 2004.

CHAVES, L. H. G.; GHEYI, H. R.; RIBEIRO, S. Consumo de água e eficiência do uso para cultivar de mamona Paraguaçu submetida à fertilização nitrogenada. Revista de Engenharia Ambiental, Espírito Santo do Pinhal, v. 08, n. 01, p. 126-133, 2011.

CONAB - Companhia Nacional de Abastecimento. Mamona - série histórica. Disponível em: $<$ http://www.conab.gov.br>. Acesso em: 11 Ago 2014.

COSTA, A. G. F.; SOFIATTI, V.; MACIEL, C. D. G.; POLETINE, G. P.; SOUZA, J. I. Weed management strategies for castor bean crops. Acta Scientarum, Agronomy. Maringá, v. 36, n. 2, 2014.

http://dx.doi.org/10.4025/actasciagron.v36i2.17090

EPSTEIN, E.; BLOOM, A. J. Nutrição mineral de plantas: princípios e perspectivas. Londrina: Editora Planta, 2006. 403p.

FAO - Food and Agriculture Oganization of United Nations. Food and agricultural commodities production. Disponível em: <http://www.fao.org>. Acesso em: 16 Ago 2014.

FERREIRA, D. F. Sisvar: a computer statistical analysis system. Ciência e Agrotecnologia (UFLA), Lavras, v. 35, n. 6, p. 1039-1042, 2011. http://dx.doi.org/10.1590/S1413-70542011000600001

FERREIRA, M. G. C.; MARUYAMA, W. I.; SORATTO, R. P. Avaliação de cultivares de mamona em dois arranjos de plantas no outono-inverno em Cassilândia-MS. Revista Brasileira de Oleaginosas e Fibrosas, Campina Grande, v. 13, n. 2, p. 53-60, 2009.

MACIEL, C. D. G.; POLETINE, J. P.; VELINI, E. D.; AMARAL, J. G. C.; ZANI, L. P.; SANTOS, R. F.; RODRIGUES, M.; RAIMONDI, M. A.; RIBEIRO, R. B. Possibilidade de aplicação de misturas de herbicidas de ação total com jato dirigido em mamoneira de porte anão. Planta Daninha, Viçosa, v. 26, n. 2, p. 457-464, 2008. http://dx.doi.org/10.1590/S0100-83582008000200023

MOSHKIN, V. A. Growth and development of the plant. In: 1986. p. 36-42. (Ed.). Castor. New Delhi: Amerind,

RENTSCH, D.; SCHIMIDT, S. TEGEDER, M. Transporters for uptake and allocation of organic nitrogen compounds in plants. Plant Transporters and Channels, Heidelberg, v. 581, n. 12, p. 2281-2289, 2007.

SEVERINO, L. S.; MILANI, M.; MORAES, C. R. A.; GONDIM, T. M. S.; CARDOSO, G.D. Avaliação da produtividade e teor de óleo de dez genótipos de mamoneira cultivados em altitude inferior a 300 metros. Revista Ciência Agronômica, Fortaleza, v. 37, p. 188-194, 2006.

SILVA, T. R. B.; LEITE, V. E.; SILVA, A. R. B.; VIANA, L. R. Adubação nitrogenada em cobertura na cultura da mamona em plantio direto. Pesquisa Agropecuária Brasileira, Brasília, v. 42, n. 9, p. 1357-1359, 2007. http://dx.doi.org/10.1590/S0100-204X2007000900018

SORATTO, R. S.; SOUZA-SCHLICK, G. D.; GIACOMO, B. M. S.; ZANOTTO, M. D.; FERNANDES, A. M. Espaçamento e população de plantas de mamoneira de porte baixo para colheita mecanizada. Pesquisa Agropecuária Brasileira, Brasília, v. 46, n. 3, p. 245-253, 2011. 
SOUZA-SCHLICK, G. D.; SORATTO, R. P.; PASQUALI, C. B.; FERNANDES, A. M. Desempenho da mamoneira IAC 2028 em função do espaçamento entre fileiras e população de plantas na safrinha. Bragantia, Campinas v. 70, n. 3, p. 519-528, 2011.

TORRES, F. E.; TEODORO, P. E.; GOMES, A. C.; HERNANDES, F. B.; FERNANDES, R. L.; RIBEIRO, L. P. Adaptability, agronomic performance and genetic divergence of castor genotypes grown in the CerradoPantanal ecotone. Revista de Ciências Agrárias, Belém, v. 58, p. 1-5, 2015a.

http://dx.doi.org/10.4322/rca.1700

TORRES, F. E.; TEODORO, P. E.; RIBEIRO, L. P.; CORREA, C. C. G.; HERNANDES, F. B.;

FERNANDES, R. L.; GOMES, A. C.; LOPES, K. V. Correlations and path analysis on oil content of castor genotypes. Bioscience Journal (Online), Uberlândia, v. 31, p. 1363-1369, 2015 b.

http://dx.doi.org/10.14393/BJ-v31n5a2015-26391

TORRES, F. E.; TOLEDO, L. R.; RIBEIRO, M. H. P. G.; TEODORO, P. E.; RIBEIRO, L. P.; CORREA, C. C. G. Influência do manejo de plantas daninhas e da adubação nitrogenada no teor de óleo em cultivares de mamona (Ricinus communis). Revista de Ciências Agrárias, Lisboa, v. 36, p. 357-362, 2013.

WEISS, E. A. Oilseed crops. London: Longman, 1983. 660p. 